\title{
イソプレンからラバンジュリルメチルエーテルの合成
}

\author{
佐 藤 槞*・木瀬 秀夫**・妹 尾 学**・浅 原 照三** \\ * 神奈川県工業試験所 (横捠市金沢区昭和町) \\ ** 東京大学生産技術研究所 (東京都港区六本木)
}

\section{Preparation of Lavandulyl Methyl Ether from Isoprene}

Tōru SAT̄̄*, Hideo Kise**, Manabu Senō** and Teruzō AsahaRA**

* Industrial Research Institute of Kanagawa Prefecture (Showa-cho, Kanazawa-ku, Yokohama)

** Institute of Industrial Science, University of Tokyo (Roppongi, Minato-ku, Tokyo)

Lavandulyl methyl ether was prepared by the following reactions : The addition of chloromethyl methyl ether to prenyl chloride in the presence of stannic chloride afforded 1,3-dichloro-2methoxymethyl-3-methylbutane, which was then treated in DMF to give the dehydrochlorination product, 2-methyl-3-methoxymethyl-4-chlorobutene-1. The Grignard reaction of the butene derivative with methallyl chloride gave lavandulyl methyl ether. The total yield of lavandulyl methyl ether was $35 \sim 40 \%$ based on isoprene.

\section{1 緒 言}

ラバンジュロールはフランス産ラベンダー油に遊離の 形でまたはエステルとして存在して特有のラベンダーの 香気を有し，高級化粧品香料として利用されている。そ れには下記のように $\alpha$ 体および $\beta$ 体の二種類の異性体が 存在する。<smiles>CC(C)CCCCC(C)O</smiles>

$\alpha$ 体<smiles>CC=CCC(CO)C(C)(C)C</smiles>

ラバンジュロールの合成に関しては,メチルヘプテノ ンを中間体とする方法"), 真化プレニルとアセト酢酸エ ステル縮合物を用いる方法 ${ }^{2)}$, 臭化プレニルと $\beta, \beta-シ ゙$ メチルアクリル酸縮合物を還元する方法 ${ }^{3)}$, 八ロゲン化 プレニルをルイス酸で二量化する方法) 等が報告されて いる。著者らはイソプレンを原料としてテルペン化合物 を選択性良く合成する方法を研究しているが，ここでは イソプレンの塩化水素付加体（[1] および [2]）とクロ ロメチルメチルエーテル (CME) とのカチオンテロメ リゼーションで得られる 1 対 1 付加体を中間体に用いる a-ラバンジュリルメチルエーテル [5] の合成法を見い だしたので，以下にその実験結果を報告する。反応経路 を式 (1) (4) に示す。<smiles>CC(C)C(C)C=CC(C)C(C)C(C)(Cl)C(C)C</smiles>

[1] または [2] $+\mathrm{ClCH}_{2} \mathrm{OCH}_{3} \frac{\mathrm{SnCl}_{6}}{\text { in } \mathrm{CH}_{2} \mathrm{Cl}_{2}}$ CME<smiles>COCC(C(CCl)OC)C(C)(C)Cl</smiles>

[3]

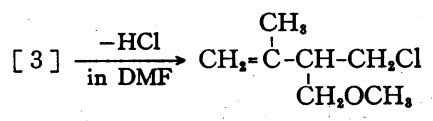
[4]

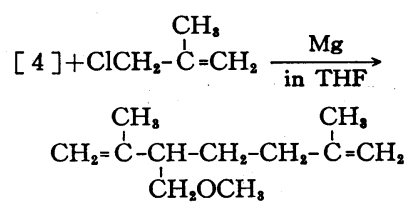
[5]

\section{2 実験および結果}

$2 \cdot 1$ インプレンの塩化水素付加体（[1] およひ [2]) とクロロメチルメチルエーテル (CME) の反応 四つロフラスコ中に CME $32.0 \mathrm{~g}(0.40 \mathrm{~mol})$ と溶 媒の塩化メチレン $100 \mathrm{~m} l$ を仕込み, 約 $5^{\circ} \mathrm{C}$ で塩化スズ (IV) $2.0 \mathrm{~m} l(0.017 \mathrm{~mol})$ を添加する。溶液をかきませ 
ながら Ultee らの方法 ${ }^{5)}$ で合成した塩化プレニル [1] と 3-クロロ-3-メチルブテン-1 [2] の混合物（[1] を 80 90\% 含む) $31.2 \mathrm{~g}(0.30 \mathrm{~mol})$ を滴下する。反応 温度を $5^{\circ} \mathrm{C}$ 前後に保ち, $2 \mathrm{hr}$ 反応後混合物を氷水 200 $\mathrm{m} l$ 中に注ぎ, 有機層を分離乾燥後溶媒を留去してから 生成物を分留した。bp $38 \sim 39^{\circ} \mathrm{C} / 2 \mathrm{mmHg}$. GLC (ポリ エステルサクシネート）上り単一成分であることを確認 した。

生成物の IR は $1,120 \mathrm{~cm}^{-1}$ と $735 \mathrm{~cm}^{-1}$ にそれぞれ $\mathrm{C}-\mathrm{O}-\mathrm{C}$ と $\mathrm{C}-\mathrm{Cl}$ の伸縮振動に基づく吸収を有する。ま た NMRの測定結果と帰属を下に示す（四塩化炭 素中, 標準物質 TMS, $s=$ singlet, $d=$ doublet, $t=$ triplet, $q u i=$ quintet, $m=$ multiplet $): 1.61(d, J=6$ $\left.\mathrm{Hz}, 6 \mathrm{H},\left(\mathrm{CH}_{3}\right)_{2} \mathrm{CCl}-\right), 2.08$ (qui, $J=4 \mathrm{~Hz}, 1 \mathrm{H}$, $-\mathrm{CH} \zeta), 3.30\left(s, 3 \mathrm{H},-\mathrm{OCH}_{3}\right), 3.5 \sim 4.0(m, 4 \mathrm{H}$, $-\mathrm{CH}_{2}-$ )。

元素分析 : 測定値 C, $45.79 \% ; \mathrm{H}, 7.85 \%$ 。

$\mathrm{C}_{7} \mathrm{H}_{14} \mathrm{OCl}_{2}$ [3] としての計算値 $\mathrm{C}, 45.54 \% ; \mathrm{H}, 7.64$ $\%$ 。

以上の結果から蒸留により単離した成分は 1,3-ジクロ ロー2-メトキシメチル-3-メチルブタン [3] であると結論 した。収量 $45.0 \mathrm{~g}$, 収率 $81 \%$ 。

\section{$2.2[3]$ の脱塩化水素}

四つロフラスコ中で [3] $92.0 \mathrm{~g}(0.50 \mathrm{~mol})$ と DMF $144 \mathrm{~g}$ とを $130^{\circ} \mathrm{C}$ で $2 \mathrm{hr}$ 加熱する。反応後 $10 \% \mathrm{HCl}$ $200 \mathrm{~m} l$ を加えて酸性として DMF を除去し, エーテル 抽出後生成物を分留し $68 \sim 69^{\circ} \mathrm{C} / 27 \mathrm{mmHg}$ の留分を得 た。IR スペクトルは $1650 \mathrm{~cm}^{-1}$ ( $\mathrm{C}=\mathrm{C}$ 伸縮) $, 1,120$ $\mathrm{cm}^{-1}$ (C-O-C 伸縮), $890 \mathrm{~cm}^{-1}\left(\mathrm{CH}_{2}=\mathrm{C}<\right.$ の $\mathrm{CH}$ 変角) および $735 \mathrm{~cm}^{-1}$ (C-Cl 伸縮) の各特性吸収を有し, NMR は下記の吸収を示した：

$1.78\left(s, 3 \mathrm{H}, \mathrm{C}-\mathrm{CH}_{3}\right), 2.58(q u i, J=7 \mathrm{~Hz}, 1 \mathrm{H}$, $>\mathrm{CH}-), 3.34\left(s, 3 \mathrm{H}, \mathrm{OCH}_{3}\right), 3.4 \sim 3.7(m, 4 \mathrm{H}$, $\left.-\mathrm{CH}_{2}-\right), 4.8 \sim 5.0\left(m, 2 \mathrm{H}, \mathrm{CH}_{2}=\right)$ 。

元素分析 : 測定值 C, 56.53\%; H, 8.82\%。

$\mathrm{C}_{7} \mathrm{H}_{13} \mathrm{OCl}[4]$ としての計算值 $\mathrm{C}, 56.57 \% ; \mathrm{H}, 8.82$ \%。以上から生成物は 2-メチルー3-メトキシメチルー4クロロブテン-1 [4] であると同定した。収量 $55.7 \mathrm{~g}$, 收率 $75 \%$ 。

\section{3 [4] とメタリルクロリドの反応}

フラスコ中に $\mathrm{Mg} 4.8 \mathrm{~g}(0.20 \mathrm{~mol})$ と THF $100 \mathrm{~m} l$ をとり加熱還流しながらメタリルクロリド $4.0 \mathrm{~g}(0.04$ $\mathrm{mol})$ を加え, さらに [4] $22.4 \mathrm{~g}(0.15 \mathrm{~mol})$ を滴下し て [4] の Grignard 試薬を調製する。反応溶液にメタ リルクロリド $18.0 \mathrm{~g}(0.20 \mathrm{~mol})$ を滴下し, さらに $25^{\circ} \mathrm{C}$ で $1 \mathrm{hr}$ 保ったのち加熱還流して $2 \mathrm{hr}$ 反応させ た。反応後 $10 \% \mathrm{HCl}$ の飽和食塩水 $100 \mathrm{~m} l$ を加え, 有 機層をエーテル抽出し, 溶媒留去後生成物を蒸留により 単離した。bp $68 \sim 69^{\circ} \mathrm{C} / 10 \mathrm{mmHg}$ 。

IR スペクトルは $1,640 \mathrm{~cm}^{-1}$ ( $\mathrm{C}=\mathrm{C}$ 伸縮) $, 1,125 \mathrm{~cm}^{-1}$ (C-O-C 伸縮) 打よび $890 \mathrm{~cm}^{-1}\left(\mathrm{CH}_{2}=\mathrm{C}<\right.$ の $\mathrm{CH}$ 変 角) の各吸収を有し, NMR および MS $(70 \mathrm{eV})$ の結 果は以下のようであった。

NMR : $1.67\left(s, 3 \mathrm{H}, \mathrm{CH}_{3}\right), 1.69\left(s, 3 \mathrm{H}, \mathrm{CH}_{3}\right)$, $1.8 \sim 2.5\left(m, 5 \mathrm{H},-\mathrm{CHCH}_{2} \mathrm{CH}_{2}-\right), 3.23(s, 3 \mathrm{H}$, $\left.\mathrm{O}-\mathrm{CH}_{3}\right), 3.30\left(d, J=6 \mathrm{~Hz}, 2 \mathrm{H},-\mathrm{CH}_{2}-\mathrm{O}-\right), 4.5$ $\sim 4.8\left(m, 4 \mathrm{H}, \mathrm{CH}_{2}=\mathrm{C}<\right)$ 。

MS : $m / e 168$ 分子イオン

$137 \mathrm{C}_{10} \mathrm{H}_{17},\left[\mathrm{CH}_{2}=\mathrm{C}\left(\mathrm{CH}_{3}\right) \mathrm{CH}\left(\mathrm{CH}_{2}\right)\right.$. $\left.\mathrm{CH}_{2} \mathrm{CH}_{2}-\mathrm{C}\left(\mathrm{CH}_{3}\right)=\mathrm{CH}_{2}\right]^{+}$

$123 \mathrm{C}_{9} \mathrm{H}_{15},\left[\mathrm{CH}_{2}=\mathrm{C}\left(\mathrm{CH}_{3}\right) \mathrm{CHCH}_{2} \mathrm{CH}_{2} \mathrm{C}\right.$. $\left.\left(\mathrm{CH}_{3}\right)=\mathrm{CH}_{2}\right]^{+}$

$99 \mathrm{C}_{6} \mathrm{H}_{11} \mathrm{O},\left[\mathrm{CH}_{2}=\mathrm{C}\left(\mathrm{CH}_{3}\right) \mathrm{CHCH}_{2}\right.$. $\left.\mathrm{OCH}_{3}\right]^{+}$

$55 \mathrm{C}_{4} \mathrm{H}_{7},\left[\mathrm{CH}_{2}=\mathrm{C}\left(\mathrm{CH}_{3}\right) \mathrm{CH}_{2}\right]^{+}$

$45 \mathrm{C}_{2} \mathrm{H}_{5} \mathrm{O},\left[\mathrm{CH}_{2} \mathrm{OCH}_{3}\right]^{+}$

元素分析 : 測定值 $\mathrm{C}, 78.24 \% ; \mathrm{H}, 12.20 \%$ 。

$\mathrm{C}_{11} \mathrm{H}_{20} \mathrm{O}[5]$ としての計算值 C, 78.51\%, H, 11.98\%。 以上の結果から生成物をラバンジュリルメチルエーテル [5] と同定した。収量 $18.5 \mathrm{~g}$, 収率 73\%。

\section{3 考察}

イソプレンの塩化水素付加体 [1] および [2] はアリ ル型塩素原子を有し, 塩化スズ (IV) の作用により容易 にカルボニウムイオンを生成して異性化および重合する ことが知られている6)。したがってこれらの反応を㧕制 して [1] および [2] よりも反応性が低いと考ええられ る CME をカチオン的に [1] または [2] に付加させる ためには塩化スズの CME 溶液に [1] と [2] の混合溶 液を滴下する方法がよい。CME が塩化スズに配位する ことにより塩化スズの活性を適度に抑制して副反応を防 ぎ, 実験の項で述べたように収率良く［3]淂られた と考えられる。

[1] および [2] に対する CME の付加反応は, 付加 の方向により数種類の異性体生成物が考えられるが, 反 応の結果は [1] から Markovnikov 則にしたがった生 成物 [3] が選択的に得られることを示している。

DMF による [3] の脱塩化水素反応では, 塩素に対 して二種類の $\beta$ 位のプロトン脱離が考えられるが, 実験 結果は脱離生成物中の約 $85 \%$ が末端プロトンの脱離に よる生成物 [4] であった。この結果は $\beta$ プロトンの数 （末端 6 個, 内部 1 個）から計算した 值とほぼ一致して おり，その意味では特に反応に選択性は認められない。 アルコールカリによる脱塩化水素も試みたが, 反応生 成物の GLC は複雑なピークを有し, [4] の収率も小さ く, [3] の脱塩化水素による [4] の合成には $\mathrm{DMF}$ が 
寸ぐれていることが明らかにされた。

[4] とメタリルクロリドのカップリング反応は, [4] の Grignard 試薬を THF 中で調製し, その溶液にメ タリルクロリドを滴下する方法を用いた。この場合 [4] と $\mathrm{Mg}$ の反応は非常に遅いため先に少量のメタリルク ロリドを Grignard 試薬化し，それと [4]の反応で [4] の Grignard 試薬を調製した。この方法によりメタリル クロリド分子間のカップリング反応を抑制し，かつ充分 な速度で [5] を合成することが可能である。なおこの 反応はジェチルエーテル中ではほとんど進行せず原料回 収に終わった。

以上述べたように, 安価かつ大量に入手可能なイソプ レンから, 温和な条件下で進行する四段階の反応を経て
ラバンジュリルメチルエーテルを比較的収率良く合成す ることができる。イソプレンから [5] への転化率は 35 〜 40\%である。

（昭和 49 年 10 月 23 日受理）

\section{文献}

1) W. Kuhn, H. Schinz, Helv. Chim. Acta, 35, 2008 (1952)

2）松井, 小林, Agr. Biol. Japan, 26, 705 (1962)

3) 松井, 小林, 日特公, 7756 (1964)

4) A.A. Petrov, J. Org. Chem. USSR, 1, 2105 (1965)

5) A.J. Ultee, J. Chem. Soc., 1948, 530

6) K.V. Leets, Zh. Obshch. Khim., 28, 3096 (1958); 浅原, 豊田, 木瀬, 工化, 72, 1529 (1969) 